
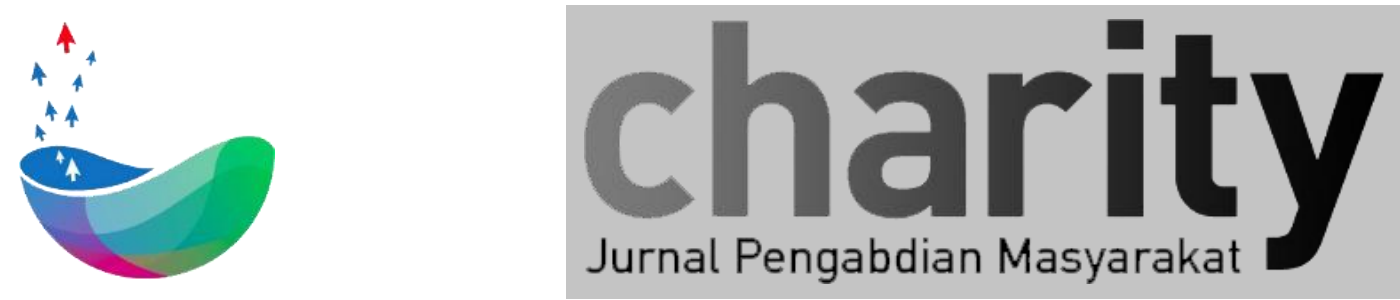

\title{
Pembangunan Marketplace Online Barang Digital Menggunakan Fitur Product Recommendation (Rating \& Tag Analytics) dan Braintree Payment System
}

\author{
Erwin Yulianto ${ }^{1}$ Fajar Nurochim ${ }^{2}$ \\ Teknik Informatika, Fakultas Teknik, Universitas Langlangbuana \\ eyulianto@unla.ac.id \\ neomuslimz@gmail.com
}

\section{INFO ARTIKEL}

Diterima 22 Juni 2020

Direvisi 21 Juli 2020

Disetujui 27 Agustus 2020

Tersedia Online 28 Agustus 2020

\begin{abstract}
ABSTRAK
Menurut riset Google, nilai transaksi e-commerce pada tahun 2019 di Indonesia mencapai US\$ 21 Milyar dan akan terus meningkat, sedangkan belum banyak perusahaan yang menyediakan aplikasi marketplace yang khusus mempromosikan barang digital kepada masyarakat sebagai salah satu potensi ekonomi Indonesia di masa depan. Penelitian ini mengambil tema Pengabdian Kepada Masyarakat melalui pengembangan aplikasi marketplace khusus barang digital. Metode pengumpulan data yang digunakan yaitu studi literatur dan observasi serta peninjauan langsung terhadap potensi peluang usaha di bidang content barang digital. Metode pembangunan perangkat lunak yang digunakan menggunakan model Software Development Life Cycle Waterfall. Fitur utama yang dikembangan pada aplikasi Marketplace Barang Digital yaitu Product Recommendation via Rating dan Tags Analytics. Produk ini diharapkan akan mampu mempromosikan barang digital kepada masyarakat luas, sebagai salah satu potensi ekonomi baru dan sumber penghasilan tambahan bagi masyarakat.
\end{abstract}

Keyword: Marketplace, Barang Digital, Product Recommendation, Rating System, Tags Analytics

Korespondensi:

Lembaga Pengabdian Masyarakat Universitas Langlangbuana

Jalan Karapitan No. 116, Kel. Cikawao, Kec. Lengkong, Kota Bandung 40261

Indonesia

E-mail : pengabdian.unla@gmail.com

ORCID ID: 0000-0002-7916-1821

Penulis Pertama: Erwin Yulianto

https://doi.org/xxx

Paper_reg_number xxxx (C) The Authors. Published by Directorate of Research and Community Service, Telkom University.

This is an open access article under the xxx license (https://creativecommons.org/licenses/xxx) 


\section{Pendahuluan}

Menurut riset google, nilai transaksi E-Commerce di Indonesia mencapai US\$ 21 Miliar pada tahun 2019. Jumlah transaksi Transaksi E-Commerce Indonesia merupakan yang terbesar di Asia Tenggara sebagaimana terlihat pada Gambar 1. Google memprediksi pertumbuhan ekonomi digital terutama E-Commerce di Asia Tenggara diprediksi akan terus tumbuh. Beberapa negara yang menjadi sorotan di kawasan ini adalah Indonesia, Malaysia, Filipina, Singapura, Thailand, dan Vietnam. Laporan e-Conomy SEA 2019 mengungkapkan bahwa rata-rata pertumbuhan ekonomi digital berada di kisaran 20-30\% sejak tahun 2015. Negara-negara di Kawasan Asia Tenggara mampu bertahan di tengah persaingan global. Indonesia dan Vietnam menjadi dua negara dengan nilai perekonomian digital terbesar. (KataData, 2019)

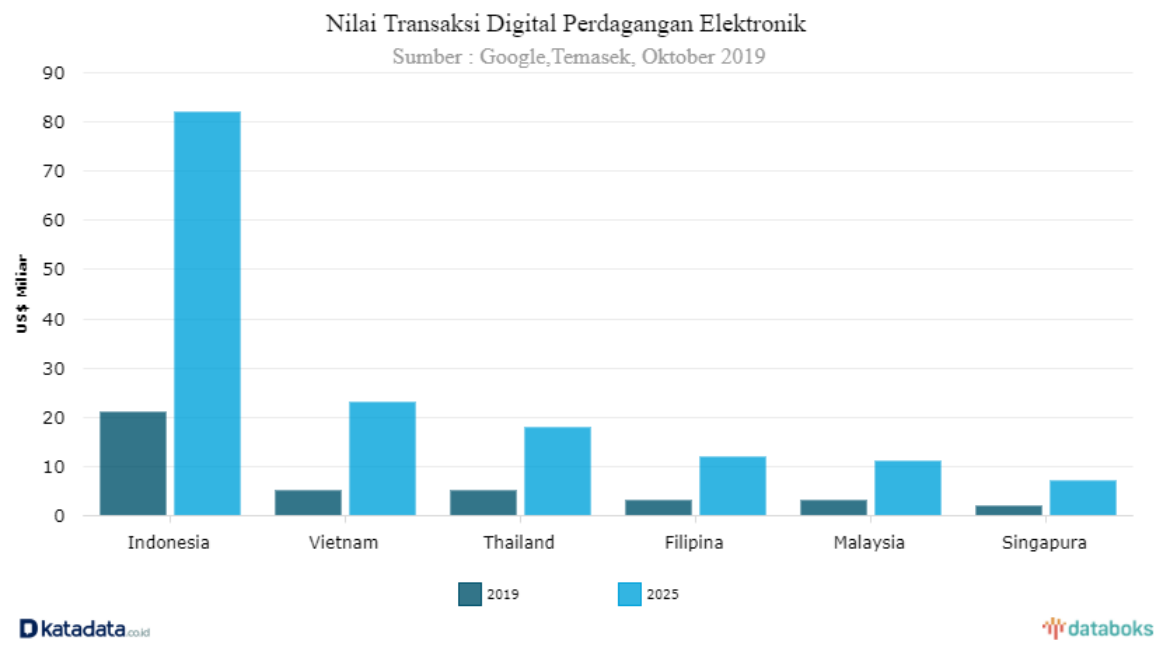

Gambar 1. Nilai Transaksi Digital Perdagangan Elektronik (Sumber : KataData, 2020)

Kemajuan teknologi membuka banyak peluang baru di bidang usaha berbasis teknologi informasi. Banyak perusahaan digital berdiri, seperti GoJek, BukaLapak, Tokopedia, Shopee dan Marketplace lainnya yang merupakan bentuk perusahaan digital yang sukses di Indonesia. Gojek membuka lapangan pekerjaan sehingga setiap penduduk Indonesia bisa menggunakan kendaraan pribadinya untuk menjadi angkutan online. Bukalapak dan Tokopedia membuka jutaan lapangan pekerjaan dengan cara memberi kemudahan untuk membuka toko secara online. Bukalapak dan Tokopedia bergerak di bidang komoditi barang fisik. Seiring berjalannya waktu, lahirlah komoditi barang non-fisik yakni barang digital berupa gambar, icon, foto, logo, kartu nama, animasi, video, musik, film, simulasi, template website dan aneka media komunikasi audio visual lainnya. Saat ini di Indonesia belum banyak wadah pasar untuk mempertemukan penjual dan pembeli untuk transaksi penjualan barang digital. 


\section{Permasalahan \& Solusi Yang Ditawarkan}

\subsection{Permasalahan}

Saat ini hanya sedikit masyarakat Indonesia yang mengetahui potensi ekonomi dari peluang usaha barang digital. Banyak sekali jenis barang digital yang bisa diproduksi baik perorangan maupun rumah usaha yang bisa menjadi penghasilan utama maupun sampingan. Barang digital yang sangat mudah diproduksi adalah foto, dimana setiap orang saat ini mampu menghasilkan foto menggunakan smartphone yang dimilikinya. Dengan sedikit sentuhan pengetahuan fotografi yang bisa dilihat di media online, foto merupakan salah satu barang digital yang memiliki nilai jual dan mudah diproduksi. Situs yang terkenal memperjualbelikan foto antara lain shutterstock dan eyeem. Tidak sedikit juga pengguna internet di Indonesia yang bertransaksi di sana.

Jenis barang digital saat ini sangat banyak, dimana setiap jenisnya memiliki potensi ekonomi di era digital ini, namun dibutuhan promosi dan edukasi bagaimana cara membuatnya yang membutuhkan kreatifitas para talenta digital indonesia, sehingga warga indonesia bisa membuka peluang usaha baru dibidang produksi barang digital. Bapak Handoko dari channel youtube-nya Handoko TV, berhasil menjual ribuan template kartu nama di situs upwork.com dan freelancer.com, dan memiliki penghasilan ratusan juta rupiah. Seorang anak SMP menjadi sukses dan diundang ke acara Hitam Putih karena menjual banyak logo untuk perusahaan Amerika dan menjadi pengusaha sukses. Banyak fotografer Indonesia memiliki penghasilan sampingan dengan menjual foto-foto beresolusi tinggi di Shutterstock dan Eyeem. Semua fakta tersebut adalah contoh kecil dari para talenta Indonesia yang berhasil memanfaatkan peluang usaha marketplace online yang melayani transaksi jenis komoditi barang digital di Indonesia.

\subsection{Solusi Yang Ditawarkan}

Berdasarkan permasalahan di atas, solusi yang dihasilkan dari penelitian ini yaitu membangun sebuah marketplace barang digital yang mempermudah masyarakat khususnya para talenta digital di Indonesia dalam mencari, menjual dan membeli produk-produk digital. Kreativitas dan inovasi para talenta digital di Indonesia dapat tersalurkan dengan sangat baik dengan adanya marketplace barang digital ini.

Secara fungsional, marketplace barang digital yang akan dikembangkan dapat dijabarkan sebagai berikut :

a. Sistem Marketplace Online mempertemukan penjual dan pembeli barang digital bagi masyarakat Indonesia serta mengkampanyekan barang digital di Indonesia dengan hanya menjual khusus barang dengan content digital seperti gambar (foto / logo / icon) beresolusi sangat tinggi, template kartu nama customized, video / film, music / sound effect, animasi / simulasi, template website, fashion design, digital book, third graphic template dan aneka media komunikasi audio visual lainnya.

b. Sistem Marketplace Online memiliki fitur security yang handal, seperti pembatasan access limited bagi user yang terverifikasi dan approved product filtering yang dilengkapi dengan identifikasi Authentic Guards. 
c. Sistem Marketplace Online memiliki fitur rating system dan tag analytic yang di-trigger oleh banyaknya produk dilihat oleh pengunjung dan tingkat peringkat kepuasan konsumen terhadap produk online yang dibeli yang selanjutnya akan dimasukkan ke dalam database product recommendation dan menentukan barang digital yang sedang trending.

d. Fungsi konfirmasi pembayaran pada Sistem Marketplace Online menggunakan Ajax dan fungsi Checkout menggunakan Braintree Payment System yang sudah memiliki fitur-fitur handal.

\section{Metode Pelaksanaan}

Metode penelitian pelaksanaan Pengabdian Kepada Masyarakat yang dilakukan menggunakan pendekatan case study research, yaitu salah satu metode penelitian dalam ilmu social dimana dalam riset yang menggunakan metode ini, dilakukan pemeriksaan yang mendalam terhadap suatu keadaan atau fenomena yang disebut sebagai kasus dengan menggunakan cara-cara yang sistematis dalam melakukan pengamatan, pengumpulan data, analisis informasi, dan pelaporan hasilnya. (Flyvbjerg, 2006)

Berikut tahapan aktivitas dalam melakukan penelitian Pengabdian Kepada Masyarakat dengan menggunakan metode penelitian studi kasus :

a. Pada tahap pertama, dilakukan aktivitas pengumpulan data dan bahan serta materi yang diperlukan. Teknik pengumpulan data yang digunakan adalah studi literature dan observasi (field research) melalui peninjauan langsung terhadap potensi peluang usaha di bidang content barang digital.

b. Studi literatur yang dilakukan yaitu dengan melakukan pencarian terhadap berbagai sumber tertulis, baik berupa buku-buku, arsip, majalah, artikel, dan jurnal, atau dokumen-dokumen yang relevan dengan permasalahan yang dikaji.

c. Dengan menggunakan teknik observasi / field research (studi lapangan), pengambilan data dilakukan secara langsung, mengamati dan mencoba berbagai sumber situs online komersil, melakukan riset atas fitur-fitur yang ada sehingga menjadi dasar pengembangan fitur baru yang belum ada.

d. Pada tahap berikutnya, penetapan Software Development Life Cycle yang digunakan dalam pengembangan aplikasi Marketplace Digital yaitu model Waterfall yang sering dinamakan siklus hidup klasik (classic life cycle) dengan pendekatan yang sistematis dan berurutan dimulai dengan pemetaan spesifikasi kebutuhan pengguna lalu berlanjut melalui tahapan-tahapan perencanaan (planning), permodelan (modeling), konstruksi (construction), dan penyerahan sistem ke pengguna (deployment) yang diakhiri dengan dukungan pada sistem Marketplace Digital yang dihasilkan.

Secara sistematis, model Waterfall yang digunakan dapat dilihat pada Gambar 2 berikut. 


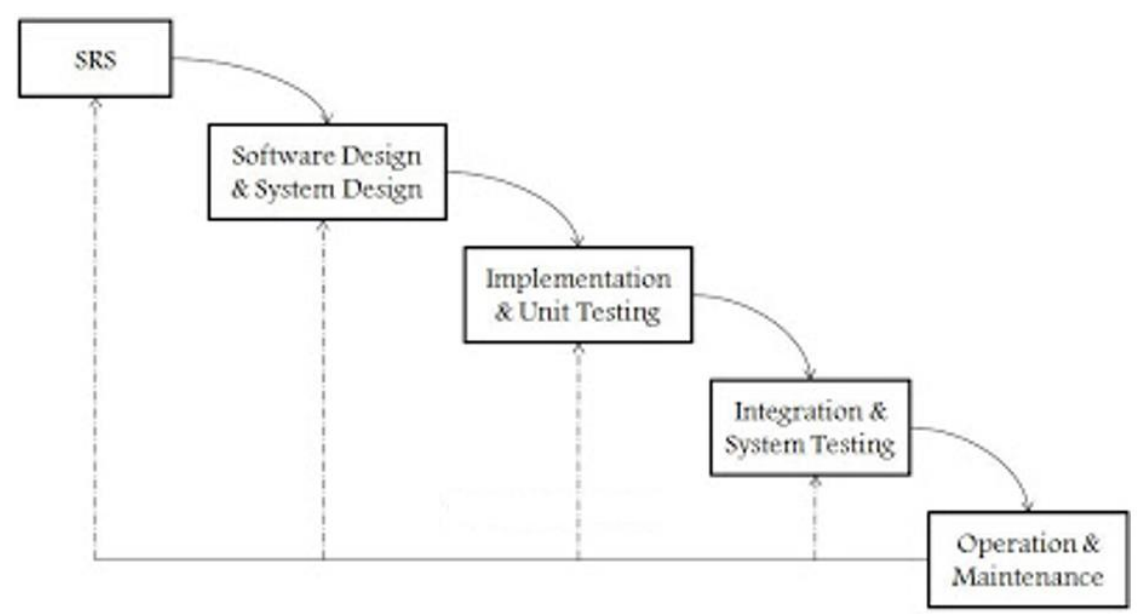

Gambar 2. Model Waterfall

(Sumber : ianswer4u, 2011)

\section{Hasil \& Pembahasan}

\subsection{Analisa Produk}

Produk yang akan dihasilkan dari kegiatan Pengabdian Kepada Masyarakat ini yaitu Marketplace Online Barang Digital. Berikut hasil analisa produk yang akan dikembangkan :

a. Marketplace Online.

Marketplace Online merupakan model bisnis online yang membantu mempromosikan barang dagangan serta memfasilitasi transaksi secara online. Marketplace menyediakan beberapa produk dari penjual online. Turban, David \& Jae (2010) mendefiniskan bahwa "Marketplace is a virtual marketplace in which sellers and buyers meet and conduct different types of transactions." Pihak situs marketplace akan mengurus penjualan dari foto produk, deskripsi, stok gudang, pengiriman barang, hingga fasilitas pembayaran. Perbedaan antara Marketplace Konvensional dan Online yaitu pembeli tidak bisa melakukan penawaran harga karena semua alur transaksi ditangani oleh marketplace online.

b. Barang Digital

Barang digital atau barang elektronik adalah barang tidak berwujud yang ada dalam bentuk digital (Wikipedia, 2019). Dalam perdagangan elektronik, barang digital adalah frasa umum yang digunakan untuk menggambarkan barang apa pun yang disimpan, dikirim, dan digunakan dalam format elektronik. Barang digital dikirim secara elektronik ke konsumen melalui email atau unduhan dari internet (webopedia, 2019).

Barang digital saat ini sudah banyak dirasakan oleh masyarakat Indonesia, namun belum banyak yang mengetahui potensi ekonominya yang besar di masa depan. Contoh barang digital adalah seperti E-Book yang dapat dibaca / diunduh melalui perangkat elektronik, musik yang dapat didengar, radio dan televisi internet serta media streaming lainnya. Selanjutnya barang-barang virtual yang membutuhkan keahlian seperti logo, foto, dan infografis, iklan online, kupon digital, tiket elektronik, token, instrumen keuangan yang diperdagangkan secara elektronik, game 
online dan dokumen online seperti workbook, worksheet, planners, elearning (kursus online); webinar, tutorial video, posting blog, web design template, fashion design dan lainnya.

c. Tags Analytics

Menurut kamus besar oxford, arti kata tag (tunggal) adalah label yang dilampirkan pada seseorang atau sesuatu untuk tujuan identifikasi atau untuk memberikan informasi lain, sedangkan dalam istilah dunia komputer, tag adalah sebuah instruksi yang ditambahkan pada sebaris teks dalam bahasa markup untuk menentukan bagaimana itu ditampilkan atau ditafsirkan (lexico, 2019). Analitika (bahasa Inggris: analytics) adalah metode atau ilmu untuk melakukan analisis logis. Penerapan umum analitika diantaranya adalah untuk mempelajari data bisnis dengan menggunakan analisis statistik untuk menemukan dan memahami pola historis demi memprakirakan dan meningkatkan kinerja bisnis pada masa depan. Analitika mirip dengan analisisis statistika dan penggalian data, namun dengan penekanan kepada pemodelan dengan menggunakan perhitungan ekstensif.

Berdasarkan hasilnya data analytics terbagi menjadi tiga jenis yaitu data analytics descriptive, data analytics predictive, dan data analytics preskriptif. Pada pengembangan Marketplace Online ini, Tags Analytics yang akan dipakai menggunakan data analytics descriptive dengan menggunakan data Tag, yaitu proses data analytics untuk mendapatkan gambaran umum dari data yang sudah dikumpulkan. Contoh dari analytics deskriptif adalah Google Analytics. Pada Google Analytics kita bisa melihat informasi sederhana seperti jumlah visitor per satuan waktu, halaman situs yang paling sering dikunjungi. Data seperti ini sangat diperlukan terutama untuk melakukan benchmarking untuk mengetahui efek dari perubahan yang kita lakukan.

Data tag ini dikumpulkan dari data pengguna atau pengunjung Marketplace Online barang digital yang dimana setiap produk memiliki banyak tag, contoh produk A memiliki 5 tag, maka pada saat produk A dilihat pengunjung, kelima tag tersebut mendapatkan satu penambahan view tag. Jumlah tag dari yang terbesar hingga yang terkecil akan diurutkan lalu diambil lima besar untuk dimunculkan pada halaman depan.

d. Braintree Payment System

Braintree, divisi PayPal, adalah perusahaan yang berbasis di Chicago yang memiliki spesialisasi dalam sistem pembayaran seluler dan perusahaan E-Commerce. Perusahaan ini diakuisisi oleh PayPal pada 26 September 2013. Braintree menyediakan klien dengan akun pedagang dan gateway pembayaran. Braintree menyediakan Library Client dan contoh integrasi dalam Ruby, Python, PHP, Java, .NET, dan Node JS; Library Mobile untuk iOS dan Android; dan Braintree.js untuk enkripsi kartu dalam browser. Braintree bekerja dengan sebagian besar platform ECommerse terkemuka, seperti BigCommerce, WooCommerce, Shopify, Magento, dan Wufoo. (braintreepayments, 2019). 


\subsection{Analisis \& Perancangan Sistem}

Setelah dilakukan analisa produk, selanjutnya dilakukan tahapan analisis dan perancangan sistem dengan tahapan-tahapan sebagai berikut :

a. Analisis Kebutuhan Pengguna

Analisis pengguna Marketplace Online sebagaimana Tabel 1 berikut bertujuan untuk membagi tugas dan hak akses dalam memetakan peran dari pengguna aplikasi yang dikembangkan.

Tabel 1. Analisis Kebutuhan Pengguna

\begin{tabular}{|c|c|}
\hline $\begin{array}{c}\text { Level } \\
\text { Otorisasi }\end{array}$ & Peran \& Hak Akses \\
\hline Admin & Mengelola Marketplace Online secara keseluruhan \\
\hline Pembeli & $\begin{array}{l}\text { 1. Mencari, membeli, memberikan rating pada barang digital } \\
\text { 2. Mengakses library barang yang dibeli dan download } \\
\text { 3. Melakukan pendaftaran sebagai penjual }\end{array}$ \\
\hline Penjual & $\begin{array}{l}\text { 1. Mencari, membeli, memberikan Tags pada barang digital } \\
\text { 2. Mengelola library barang yang dijual } \\
\text { 3. Upload dan menjual barang digital } \\
\text { 4. Akses halaman kelola barang } \\
\text { 5. Akses halaman rekapitulasi penjualan } \\
\text { 6. Akses halaman isi alamat dan billing }\end{array}$ \\
\hline
\end{tabular}

b. Analisis Proses Bisnis

Proses bisnis adalah suatu kumpulan aktivitas atau pekerjaan terstruktur yang saling terkait untuk menyelesaikan suatu masalah tertentu atau yang menghasilkan produk atau layanan demi meraih tujuan tertentu. Proses bisnis dapat dipecah menjadi beberapa sub proses yang masingmasing memiliki atribut sendiri tetapi juga berkontribusi untuk mencapai tujuan prosesnya. Penggambaran proses bisnis untuk sistem Marketplace Online yang dibangun dapat dilihat pada Gambar 3 berikut.

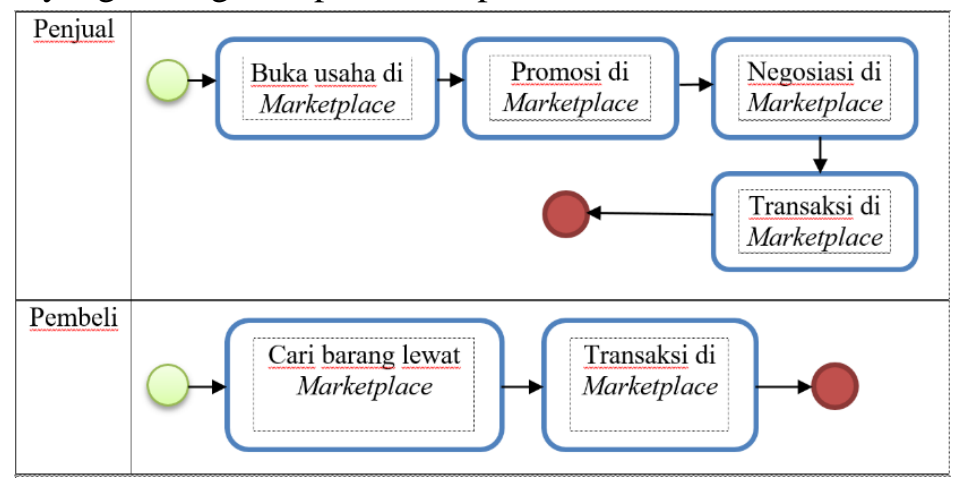

Gambar 3. Analisis Proses Bisnis

c. Analisis Kebutuhan Fungsional

Analisis kebutuhan fungsional ini bertujuan untuk memberi penjelasan berupa kebutuhan yang akan dilakukan oleh sistem terhadap masing-masing penggunanya. Berikut Tabel 2 menjelaskan kenbutuhan fungsional Marketplace Online yang sedang dikembangkan.

Tabel 2. Analisis Kebutuhan Fungsional

\begin{tabular}{|l|l|l|}
\hline \multicolumn{1}{|c|}{ Menu } & \multicolumn{1}{|c|}{ Keterangan } & \multicolumn{1}{c|}{$\begin{array}{c}\text { Kategori } \\
\text { Pengguna }\end{array}$} \\
\hline Login & $\begin{array}{l}\text { Digunakan untuk proses masuk kedalam halaman utama } \\
\text { sistem dengan memasukan Username dan Password }\end{array}$ & $\begin{array}{l}\text { Admin, Penjual, } \\
\text { Pembeli }\end{array}$ \\
\hline
\end{tabular}




\begin{tabular}{|c|c|c|}
\hline Menu & Keterangan & $\begin{array}{c}\text { Kategori } \\
\text { Pengguna }\end{array}$ \\
\hline Register & $\begin{array}{l}\text { Halaman untuk mendaftarkan diri dan membuat akun di } \\
\text { marketplace }\end{array}$ & $\begin{array}{l}\text { Penjual, } \\
\text { Pembeli }\end{array}$ \\
\hline Account & $\begin{array}{l}\text { Halaman akun untuk mengganti password, dan akses library } \\
\text { yakni halaman untuk melihat produk yang dibeli / dijual }\end{array}$ & $\begin{array}{l}\text { Admin, Penjual, } \\
\text { Pembeli }\end{array}$ \\
\hline Dashboard & $\begin{array}{l}\text { Digunakan sebagai halaman utama yang berisi semua menu } \\
\text { pengelolaan. Halaman utama marketplace dimana user } \\
\text { mendapatkan penawaran produk dari marketplace yang } \\
\text { sudah disisipkan Tags Analytics. }\end{array}$ & $\begin{array}{l}\text { Admin, Penjual, } \\
\text { Pembeli }\end{array}$ \\
\hline Users & Halaman untuk mengelola semua user yang terdaftar & Admin \\
\hline Transactions & $\begin{array}{l}\text { Halaman untuk melihat pencatatan transaksi jurnal } \\
\text { perjualan user, dan barang yang dimiliki user }\end{array}$ & Admin \\
\hline Carts & Halaman untuk melihat dan mengelola keranjang & Admin \\
\hline Orders & $\begin{array}{l}\text { Halaman untuk melihat checkout yang dibuat oleh user } \\
\text { sudah dibayar atau belum, dan menyimpan catatan id } \\
\text { transaksi pembayaran paypal/ kartu kredit jika sudah di } \\
\text { bayar. }\end{array}$ & Admin \\
\hline User Address & $\begin{array}{l}\text { Halaman pengelolaan alamat user untuk proses } \\
\text { pembayaran }\end{array}$ & Admin \\
\hline User Checkout & Halaman untuk Checkout / tagihan & Admin \\
\hline Curated Product & $\begin{array}{l}\text { Halaman untuk mendaftarkan produk yang ingin } \\
\text { ditampilkan di halaman depan secara manual }\end{array}$ & Admin \\
\hline My Product & Halaman pengelolaan produk & Admin, Penjual \\
\hline Product Rating & Halaman pengelolaan rating produk & Admin \\
\hline Product & Halaman pengelolaan produk & Admin \\
\hline Thumbnails & $\begin{array}{l}\text { Halaman Pengelolaan Gambar Thumbnail yang di-generate } \\
\text { otomatis oleh sistem }\end{array}$ & Admin \\
\hline Tags & $\begin{array}{l}\text { Halaman yang berisi tag-tag yang dibuat oleh user pada } \\
\text { saat register produk baru untuk dijual. User bisa melihat } \\
\text { seluruh tags yang sudah ada dan bisa mencari produk } \\
\text { berdasarkan tags yang ada. }\end{array}$ & $\begin{array}{l}\text { Admin, Penjual, } \\
\text { Pembeli }\end{array}$ \\
\hline Library & $\begin{array}{l}\text { Halaman dimana produk yang sudah dibeli disimpan, user } \\
\text { bisa akses dan download produk miliknya. }\end{array}$ & Pembeli \\
\hline Seller & $\begin{array}{l}\text { Halaman untuk mengakses halaman penjual, jika belum } \\
\text { terdaftar sebagai penjual akan menampilkan User } \\
\text { Agreement untuk pendaftaran sebagai penjual. }\end{array}$ & $\begin{array}{l}\text { Penjual, } \\
\text { Pembeli }\end{array}$ \\
\hline Product Detail & $\begin{array}{l}\text { Halaman satuan produk secara mendetail. Menampilkan } \\
\text { akses download dan preview jika sudah dibeli, dan tombol } \\
\text { add to cart jika belum dibeli. Menampilkan akses vendor } \\
\text { produk yang bersangkutan yang akan menampilkan seluruh } \\
\text { produk yang dijual oleh penjual tersebut. }\end{array}$ & Pembeli \\
\hline Vendor Product & Halaman seluruh produk yang dijual oleh satu penjual & Pembeli \\
\hline $\begin{array}{l}\text { Seller } \\
\text { Dashboard }\end{array}$ & Halaman yang menampilkan rekap dan rincian penjualan. & Penjual \\
\hline Transaction & $\begin{array}{l}\text { Menampilkan daftar seluruh transaksi yang sudah } \\
\text { dilakukan pada periode tertentu. }\end{array}$ & $\begin{array}{l}\text { Penjual, } \\
\text { Pembeli }\end{array}$ \\
\hline
\end{tabular}

d. Perancangan Use Case Diagram

Use Case Diagram dari Marketplace Online Barang Digital sebagaimana Gambar 4 berikut menjelaskan interaksi yang terjadi antara aktor dengan sistem maupun interaksi antara sistem itu sendiri dengan sistem lain yang terkait. Sebuah Use Case direpresentasikan dengan urutan langkah yang sederhana. 


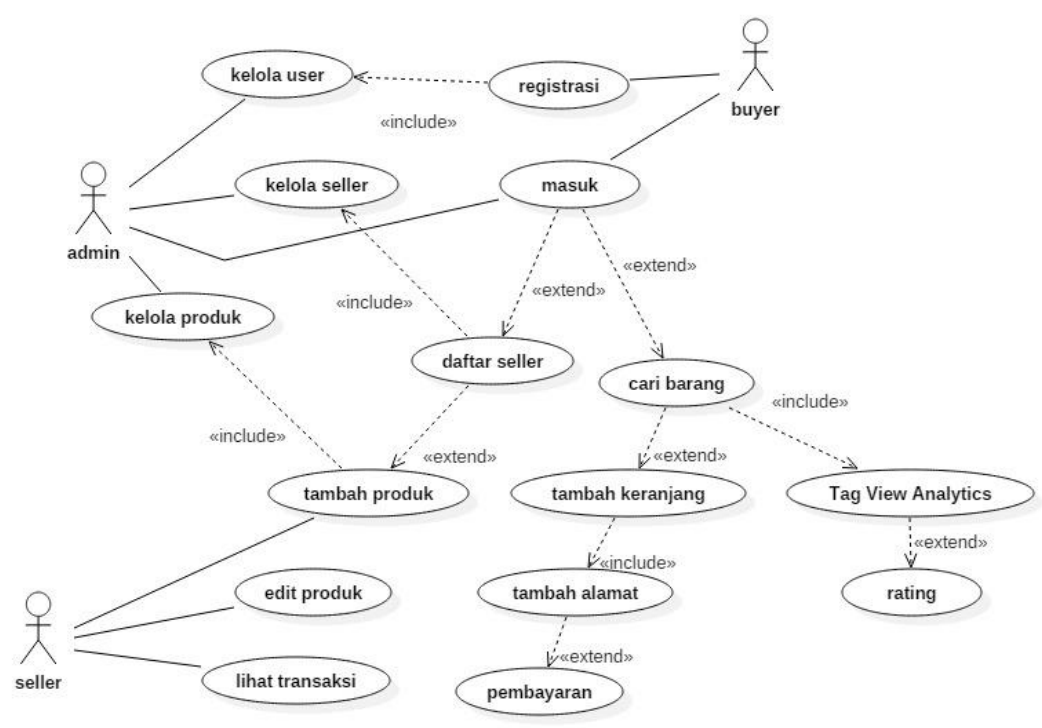

Gambar 4. Use Case Diagram

\subsection{Implementasi Sistem}

Tahapan selanjutnya setelah disepakati anasisi dan perancangan sistem yang dilakukan yaitu implementasi sistem sebagai berikut :

a. Instalasi Tags Analytics

Berikut class TagView yang berada dalam modul analytics :

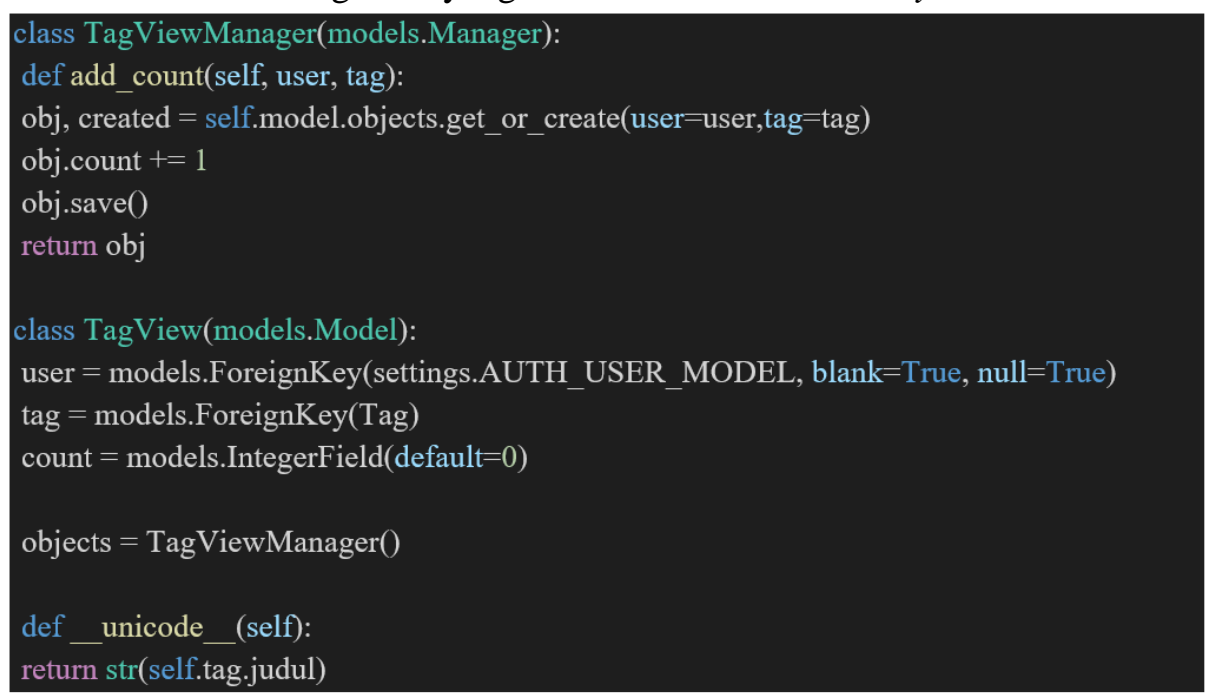

Selanjutnya kita memanggil fungsi add_count setiap kali ada produk dilihat oleh pengunjung sebagai berikut :

\section{$\operatorname{tag}=$ self.get_object() \\ new_view $=$ TagView.objects.add_count(self.request.user, tag)}

Baris kode di atas berada di controller dan view untuk product detail dan tag detail sehingga setiap kali pengunjung melihat produk atau tag, akan diregister beserta user pembuat produk dan ditambahkan jumlah view-nya. Data tag yang memiliki jumlah view terbanyak akan diurutkan ke dalam 5 terbesar yang digunakan untuk rekomendasi produk pada halaman dashboard. 
b. Implementasi Antar Muka

Berikut merupakan implementasi antarmuka dari Marketplace Online Barang Digital yang dikembangkan :

i. Halaman Admin

Halaman Admin sebagaimana Gambar 5 adalah halaman yang disediakan oleh Django Framework yang bernama Django Administration sebagai dashboard seluruh menu-menu yang dapat diakses oleh Admin.

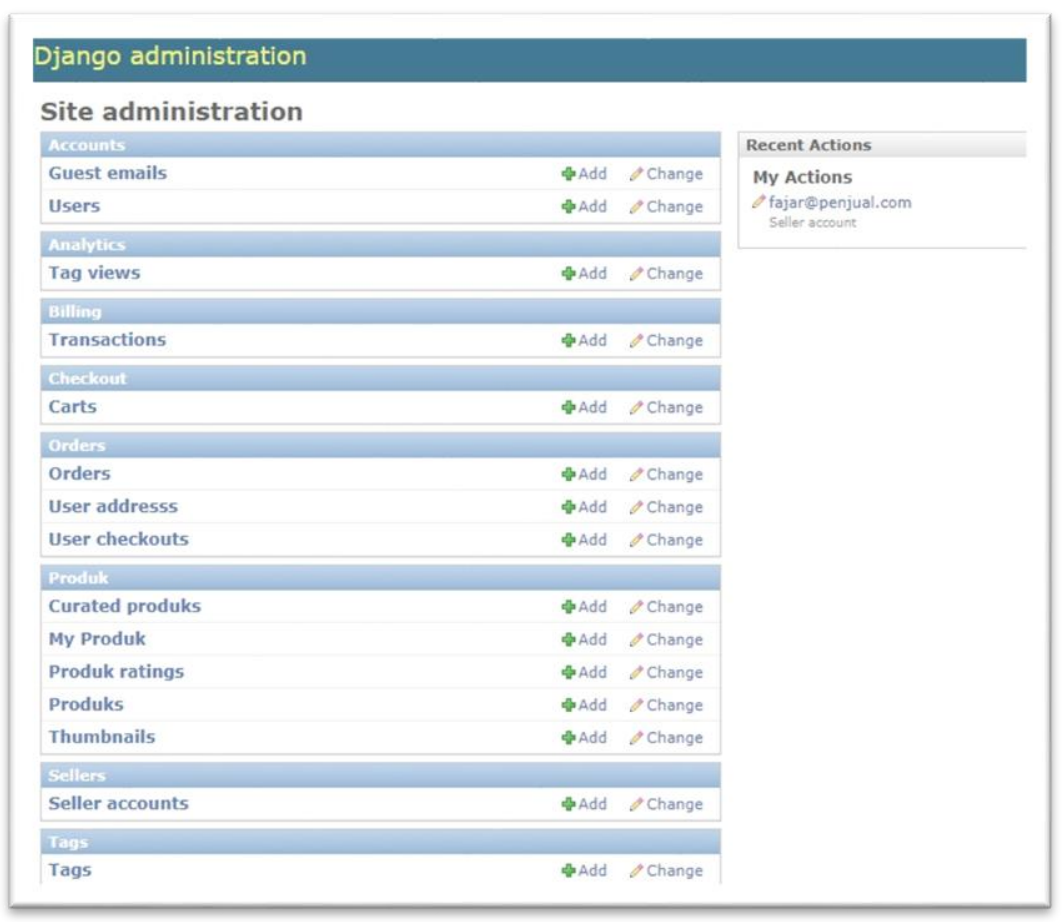

Gambar 5. Halaman Admin

ii. Halaman Tags

Halaman Tags sebagaimana Gambar 6 berisi tag-tag yang sudah terdaftar. Tag ini bisa digunakan pengguna untuk mencari produk yang berhubungan dengan tag tertentu.

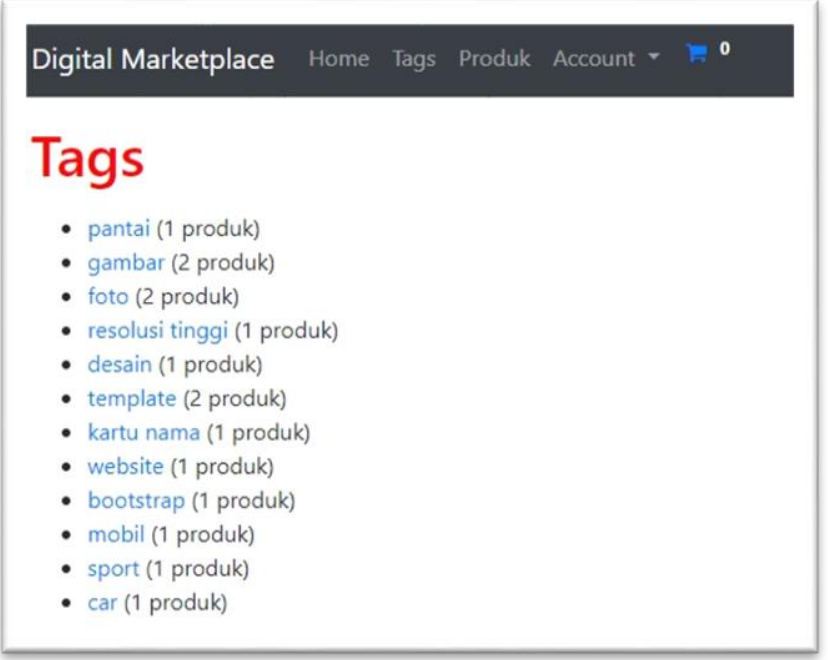

Gambar 6. Halaman Tags 


\section{iii. Halaman Product Details}

Halaman Product Details sebagaimana Gambar 7 merupakan halaman khusus dari satu produk secara lebih terperinci. Pada Menu ini terdapat tombol tambah ke keranjang serta rating untuk memberikan nilai produk

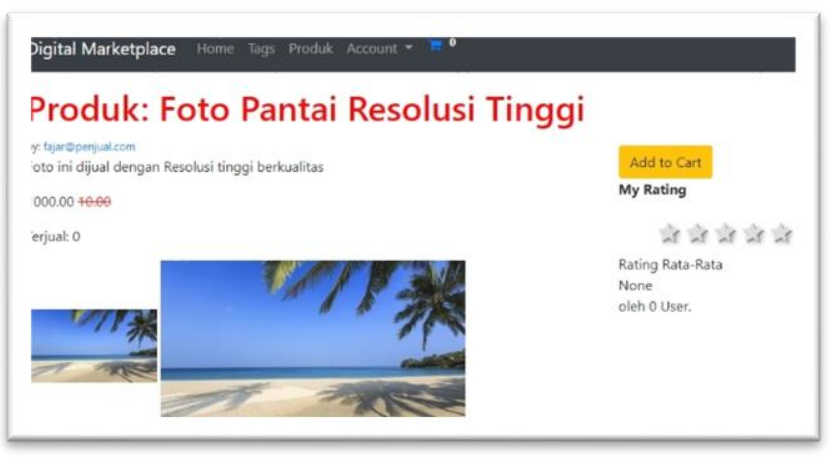

Gambar 7. Halaman Product Details

iv. Halaman Keranjang

Halaman Keranjang sebagaimana Gambar 8 berisi produkproduk yang sudah ditambahkan ke dalam keranjang oleh pengguna sebelum membayar. Pada menu ini ditampilkan jumlah total yang harus dibayar.

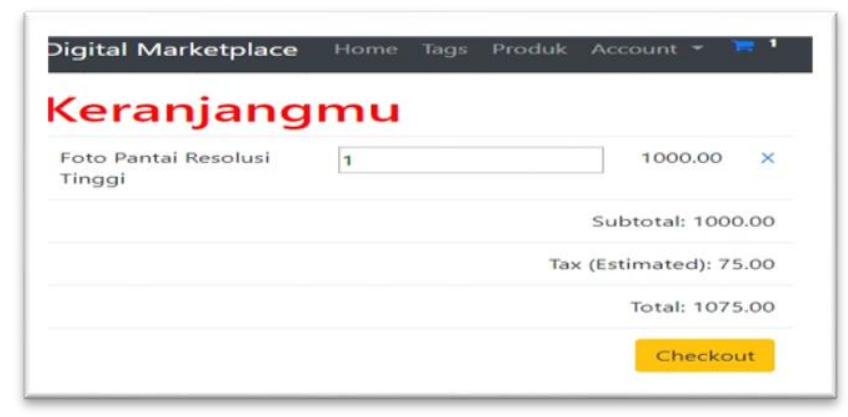

Gambar 8. Halaman Keranjang

v. Halaman Pembayaran

Halaman Pembayaran sebagaimana Gambar 9 berisi ringkasan pembayaran yang harus dibayar. Pengguna bisa memilih metode pembayaran dan menampilkan total item yang harus dibayar.

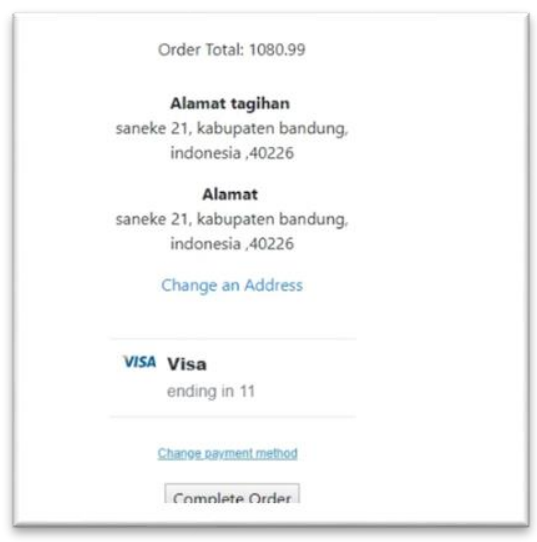

Gambar 9. Halaman Pembayaran 
vi. Halaman Daftar Produk Penjual

Halaman Tags sebagaimana Gambar 10 halaman khusus penjual yang menampilkan produk-produk yang sudah di-upload.

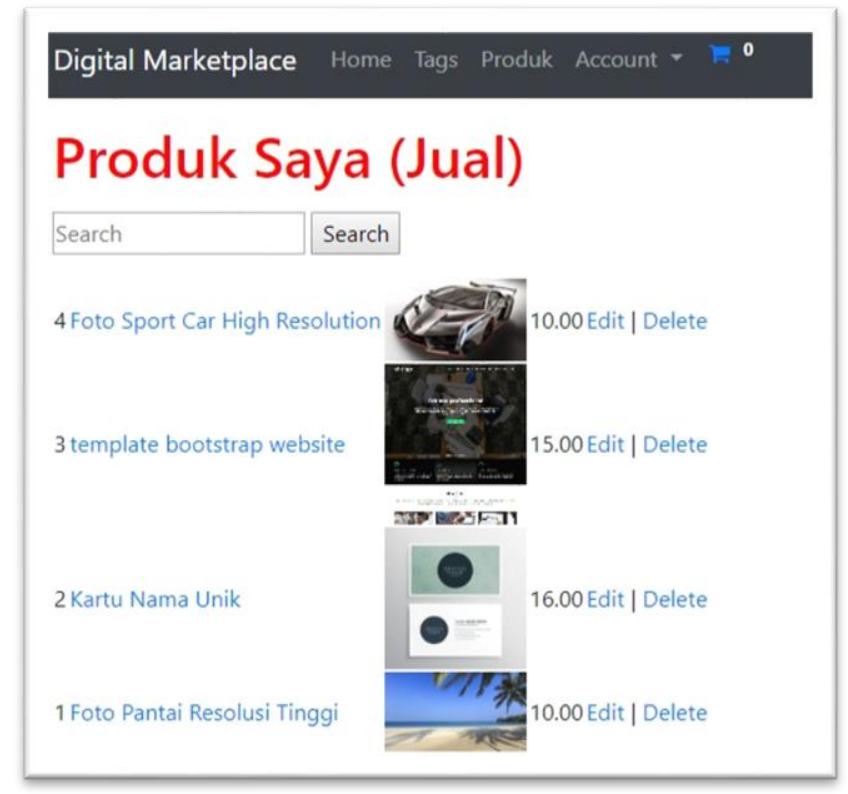

Gambar 10. Halaman Tags

\section{Kesimpulan}

Marketplace Online Barang Digital yang telah dikembangkan mampu mempertemukan penjual dan pembeli barang digital bagi masyarakat Indonesia serta mengkampanyekan barang digital di Indonesia sebagai peluang usaha baru yang potensial. Sistem Marketplace Online memiliki fitur security yang handal dan memiliki fitur rating system dan tag analytic sebagai tools untuk memberikan product recommendation dan menampilkan barang digital yang sedang trending serta penggunaan fungsi Braintree Payment System sebagai media pembayaran yang aman dan cepat.

\section{DAFTAR PUSTAKA}

[1] Braintree, "Braintree Setup and Integration", 2019. [Online]. Available : https:// developers.braintreepayments.com/guides/drop-in/setup-and-integration/java script/v2. [Diakses 03 Agustus 2019].

[2] Flyvbjerg, Bent, "Five Misunderstandings About Case Study Research", 2006. Qualitative Inquiry, Vol. 12, No. 2, pp. 219-245

[3] ianswer4u, "Waterfall Model of SDLC", 2011. [Online]. Available : https://www. ianswer4u.com/2011/11/waterfall-model.html. [Diakses 28 Maret 2020].

[4] KataData, "Transaksi E-Commerce Indonesia Terbesar di Asia Tenggara", 2020. [Online]. Available : https://databoks.katadata.co.id/datapublish/2019/10/10/nilaitransaksi-digital-perdagangan-elektronik-indonesia-terbesar-di-asia-tenggara. [Diakses 28 Maret 2020]. 
[5] Lexico, "Tag", 2019. [Online]. Available : https://www.lexico.com/en/definition/tag. [Diakses 02 Mei 2019].

[6] Turban E., David K., Jae Lee \& Liang TP. “Electronic Commerce 2010”, 2010. Pearson Education Publisher

[7] Webopedia, "Digital Goods" 2019. [Online]. Available : https://www. webopedia.com/TERM/D/digital_goods.html, [Diakses 31 Agustus 2019].

[8] Wikipedia, "Digital Goods", 2019. [Online]. Available : https://en.wikipedia.org/ wiki/Digital_goods\#cite_note-1, [Diakses 31 Agustus 2019]. 